\title{
Becoming Literacy Leaders: Teacher Candidates Initiate a Community-Based Literacy Program
}

\author{
TARA-LYNN SCHEFFEL \\ Nipissing University
}

\begin{abstract}
This paper presents a case study of a community-based literacy program that was initiated by teacher candidates. Program goals, purposes and opportunities for ongoing learning beyond coursework and practicum are explored. Key themes for discussion include: literacy as social and life-long; moving beyond print literacy; capitalizing on strengths; freedom in planning and freedom from assessment; feedback from the community; and, the opportunity to become literacy leaders. Mentorship roles are explored, along with questions for ongoing reflection and conversation.
\end{abstract}

\section{Introduction}

I have gained a unique experience by being a part of the Let's Read! team. The program has been a great outlet for my creative energies as a teacher candidate, and has made me a much more confident and competent teacher. It would be difficult to imagine my university career without being part of Let's Read! I am proud to say I have contributed to such a fantastic, successful program! (Jordyn, teacher candidate)

The program Jordyn describes is a community-based literacy initiative in Northern Ontario, designed and implemented by teacher candidates, and offered free to the local community since 2008. When I assumed a faculty position in 2009, I became familiar with the program during class discussions/assignments as teacher candidates who volunteered in the program shared theory-practice connections or asked for planning advice. As I interacted with them, I was struck by the way they had created a space beyond their coursework to put theory into practice. Unlike other volunteer learning opportunities, this literacy program was student-run and designed.

As a teacher educator who reflects constantly on moments of engagement, my curiosity about the program was piqued. I decided to initiate a study with the goal of learning more about the program, including its history, goals, and the ways in which teacher candidates might be implementing concepts discussed both from within or outside of their Language Arts coursework. The research questions I posed included:

1. What contributed to the growth and ongoing goals of Let's Read!?

2. What challenges or limitations, both within the university and the community, does Let's Read! face?

3. In what ways does Let's Read! support, challenge or prompt teacher candidate's understandings of teaching/learning language arts and literacy?

This paper explores what I learned from the teacher candidates, specifically those taking a leadership role with Let's Read!, and includes a consideration of my evolving role as teacher educator, researcher, and advisor to the program. 
The Program: What is Let's Read!?

Now in its seventh year, Let's Read! aims

...to develop authentic literacy skills and enthusiasm for learning through dynamic and engaging programming, facilitated by a group of encouraging teacher candidates who model and support interaction with a variety of text forms and activities. (Let's Read! Vision Document, p. 4)

A key role in the program is played by the two Program Leaders who are responsible for the program as a whole, lead the information sessions, design and implement programming, and serve as a point of contact with community resources, such as the local library where the program is conducted. Most Program Leaders assume the co-leadership role for 2-3 years. The leadership role was integrated into the design of the program by its original creators:

Incoming Program Leaders are selected one year prior to their start date, and are mentored into their positions by shadowing the outgoing Program Leaders. (Let's Read! Vision Document, p. 12)

Leaders hold their positions until their graduating year, during which time they hand over the reigns to the new leaders. This consistent pattern contributes to the mentoring of peers as teacher candidates earlier in their Concurrent degree program have the opportunity to work with and observe those further along in their coursework.

Each year, information sessions are held for potential Reading Mentors who will work one-to-one or in small groups with children. Interested prospective Reading Mentors submit an application and police record check to the Program Leaders, who then make a selection of Reading Mentors and develop a volunteer schedule.

Since its inception, Let's Read! has more than doubled the number of children partcipating and currently runs for five alternating Saturdays each fall and winter term. Programming is geared towards children aged 8-12, with two, one-hour sessions each Saturday. Parents register their children in advance, most selecting all of the sessions offered each term.

Though membership has grown and changed over time, current involvement in the program includes:

- Program Leaders: 2 paid positions (10 hrs. per week), 1 volunteer position for volunteer recruitment

- Reading Mentors: 30-40 volunteer positions

- Faculty Advisor

- Children in the Community: 40-60 children (20-25 per session)

My role was initially that of teacher educator and researcher until 2013 when I was invited by the teacher candidates to assume a Faculty Advisor role as the program grew and received financial and adminstrative support from the university. As Faculty Advisor, I offer planning support, share resources, and participate alongside the Program Leaders in achieving the program's vision. I also serve a liaison role with the university. 


\section{Exploring the Literature}

Although a literature search reinforced the uniqueness of Let's Read! in its design and conception, the exploration of theory-practice connections amongst teacher candidates' experiences, including the benefits of tutoring and partnership programs offered alongside specific courses during teacher education programs, is not at all unusual (Assaf \& Lopez, 2012; Chicola \& Ceprano, 2009; Garner \& Rosaen, 2009; Iannacci \& Graham, 2010; Richards, 2007; Smith, 2008). Similarly, opportunities for collaboration and community-building through service learning (Baker \& Murray, 2011; Roessingh, 2012; Wasserman, 2009), and the practices of teacher candidates beyond student teaching (Clift \& Brady, 2005, Grossman et al., 2000; Kosnik \& Beck, 2008) are equally well-documented.

Considering this body of related literature, I pondered what happens when a program is not connected with course-work but is something that teacher candidates themselves seek and develop based on the experiences they want to build in conjunction with their degree. Specifically, what is gained by Program Leaders who mentor less experienced peers?

Richards (2006) noted there are few studies examining collaboration between preservice teachers and their more experienced peers. Richards (2007) writes about a summer literacy camp she developed to meet the needs of at-risk children and to create a community of practice learning opportunity for those leading the camp. Though the camp was held in conjunction with course-work in both a pre-service and a graduate summer course, it was geared to developing an expert-novice mentorship between the two groups, a goal simliar to that underlying Let's Read! as is discussed throughout this paper. In the conclusion, Richards (2006) pondered the ways in which:

...preservice teachers' development results not from faculty-driven discourse, but from their participation in a social environment that provides rich opportunities to solve real-life problems and occassions to 'use the world around them as a learning resource.' (Wenger, 1998, p. 275, cited in Richards, 2006, p. 788)

Similarly, I consider the opportunities provided beyond coursework for teacher candidates who participate in Let's Read!

\section{Theoretical Framework}

The theoretical framework guiding this study is sociocultural and emphasizes the social nature of literacy learning (Vygotsky, 1978). In particular, this work is informed by the course text used with teacher candidates (Bainbridge \& Heydon, 2013), which recognizes literacy as multi-faceted and complex, and offers teaching suggestions aimed at enacting multiliteracies pedagogies. Specific concepts underpinning multiliteracies pedagogies include: whole-part-whole instruction (Purcell-Gates \& Waterman, 2000); gradual release of responsibility; multimodal literacy (including various modes of expression such as digital and print media); funds of knowledge (González, Moll \& Amanti, 2005); ongoing professional development; and critical reflection, including discrimination of resources and strategies in relation to context. Cambourne's (1988) conditions for learning (immersion, demonstration, expectation, responsibility, use, response, approximation, and engagement) are viewed as central to understanding literacy pedagogies within the text. These conditions are also at the forefront of my own teaching practice. 
Speaking to the importance of "develop(ing) critically reflective decisions about how to teach" (p. 35), Bainbridge and Heydon (2013) convey that this is "a process that takes time, and educators can be challenged at all stages of their careers depending on the demands of the circumstances" (p. 35). For teacher candidates in this study, the course text, and other related course material, set the stage for learning about theory and practice, offering a foundation from which to draw upon as they participate in Let's Read! Course assignments were geared towards connecting theory with practice to understand the why behind teaching decisions. Keeping Pat Smith's (2002) 4 lenses in mind, assignments also recognized the ways in which teaching/learning opportunities may be enhanced through the use of multiple viewpoints, including our own autobiography, our students' eyes, our colleagues' eyes and the literature.

\section{Methodology}

The methodology is qualitative in nature and takes an exploratory case study approach to evaluating the "case" of Let's Read! An exploratory case study is often prompted by the "need to know more: what is happening and why?" (Thomas, 2011, p. 104). In the case of Let's Read!, I had some knowledge and familiarity with the program but needed to explore further to better understand its history, design and potential. Dyson and Genishi (2005) write:

Any educational setting - a classroom, a school, a family, a community program - is overflowing with human experiences and with human stories. Researchers make decisions about how to angle their vision on these places, depending on the interplay between their own interests and the grounded particularities of the site. (p. 12)

My researcher lens was initially angled towards the Program Leaders, and built outwards as I sought to learn more.

Over a span of three years, I used multiple research methods to widen the angle of my vision (Dyson \& Genishi, 2005) and involve others participating with the program, including:

- Ongoing Focus Group Discussions with Program Leaders (April 2012, May 2013, May 2014);

- Interview with Student Initiatives Coordinator (April 2012);

- Online survey with Reading Mentors, followed by optional focus groups for those interested (March 2013);

- Follow-up Online Survey to incorporate new Reading Mentors (March 2015);

- Ongoing observations during Fall/Winter sessions (Fall/Winter 20132015).

Specific data sources included: focus group/interview transcripts, online surveys, and researcher reflections. Transcripts ranged from 16-50 pages, with groups of 3-5 participants per focus group. Participants were given a copy of their transcript, along with an invitation to clarify/elaborate additional points via email. Program-related artifacts (e.g., vision document, marketing and planning materials, etc.), as well as observations of the program in action, also contributed to overall understandings of the program and its history. In addition, course-related assignments from the Program 
Leaders were used to examine connections with and beyond coursework. In total, 30 teacher candidates contributed to the data generated (5 Program Leaders, 25 Reading Mentors).

Teacher candidates were all approximately 20-22 years of age during their time as Reading Mentors and/or Program Leaders. Program Leaders from each year of the program's duration, including one of the originators of the program, are represented. I was the instructor in the Language Arts courses taken by three of the Program Leaders in this study. All data from Program Leaders was collected following the completion of coursework.

Analysis included reading/re-reading of the transcripts and survey responses for themes arising, including points of agreement and contradiction, as well as direct and indirect references to literacy concepts. Themes were then discussed with the Program Leaders for accuracy of understanding. Course-related assignments offered a point of reflection in relation to the themes.

\section{Themes Arising}

Data analysis revealed several themes related to the program's goals and the learning opportunities for teacher candidates. These themes point to understandings about the complexity of literacy and the need to capitalize on the strengths of learners, as well as key program elements that led teacher candidates to feel successful in their literacy teaching. Supporting quotes share the voices of teacher candidates, in particular the Program Leaders who had much to say about their roles and visions for the program. Program leaders included Melanie, one of the originators of the program, followed by Jordyn and Kendra, and then Mira and Jo. Program Leaders' quotations are embedded within each thematic narrative so as not to interrupt flow. All quotes are drawn from the focus group transcripts unless otherwise cited. All names, including the name of the program, are pseudonyms.

\section{Literacy as Social and Life-long}

A key theme identified by teacher candidates was the goal of fostering lifelong learning through everyday tasks. As Kendra explained, "it's not necessarily just about reading books and enjoying them but it's also about everyday literacy..." The notion of authentic literacy was central to Program Leader's planning as further explained by Jordyn: “...they're learning how to write a magazine article...learning how to write a poem...learning how to go through the steps so [they] can use that in other aspects of real life..." Kendra agreed, adding that these were "...skills and things that they can use outside the program, like going through a recipe...will help them later in life..." Kendra had spoken to a similar goal in her final course assignment as she shared her emerging philosophy of Language Arts. Using the image of a tree to represent key concepts, one branch conveyed her goal of "literacy for life," followed by the goal to "teach what they need to learn, like how to write a letter, to make their learning authentic." This belief hearkened back to a class discussion about the work of Victoria Purcell-Gates (1996, 2008) and real-life texts for real-life purposes. Kendra had recognized that "without real-life contexts that call for reading and writing, there can be no authentic literacy in the classroom" (Purcell-Gates, 2008, p. 56). Now working within a community initiative with similar authentic literacy goals, Kendra was adapting her understandings of literacy to focus on the larger purpose of creating life-long, authentic literacy tasks for children within the community. 
Embedded within this purpose was recognition of the social nature of learning and the building of rich opportunities for talk between children and Reading Mentors. Melanie explained, "they see these adults who are excited and having fun with literacy, who aren't their parents..." The idea of time spent to share this belief was also considered important: "...when they bring in a book and they have a volunteer who just sits there and talks to them for five minutes... who does that, right?" (Melanie). Taylor's (1983) work on family literacy is echoed here as teacher candidates recognized the importance of literacy as social.

Furthering their own learning was another key aspect for many who got involved with Let's Read!, especially the Reading Mentors. Sharing their reasons for involvement, survey comments included:

- "to get more involved with children and to gain experience with teaching and helping with literacy" (2013)

- "to extend my experience working with children, and apply my learning techniques somewhere outside of the classroom" (2013)

- "small amount of time to help out and get more experience" (2013)

- "to get more experience working with children of different ages" (2015)

- "to gain more experience working with children and building on techniques to use in the classroom to help students meet their literacy needs" (2015)

Looking towards future goals, there was also a sense that "learning is a continual entity, something that doesn't simply stop when you reach a certain age" (2013). Within this community initiative, learning did not stop beyond the university classroom as teacher candidates sought to create authentic, social and life-long learning opportunities for themselves and for local children.

\section{Moving Beyond Print Literacy}

This second theme speaks to a recurring sense of being able to move beyond print literacy, a profound realization for many teacher candidates as they come to understand that literacy is more than just reading and writing. Learning about the six dimensions of language arts (reading, writing, speaking, listening, viewing, representing) is often a spark towards this understanding. Kendra and Jordyn, for example, both shared these six dimensions on their philosophy assignment as one of the main concepts they were taking away from the course. Yet, utilizing the six dimensions of language arts gained new meanings as they sought to balance expectations of creating a product for children to bring home to parents with that of creating rich learning opportunities that moved beyond only reading and writing. Kendra explained:

...we tried not to just read a book with the group...[we] took different things that we learned from curriculum methods and from literacy and used them so that it wasn't so like classroom, like sit down and read a book and then we'll go to the tables to do our handout sort of thing...more hands-on..."

Similarly, Melanie added, 
...we stick with the handouts so that...the children have something to take home....It's not just 'here's the worksheet now we've done the activity'...it's more of 'you pick what activity you want to do after reading' - so they have a choice.

It was at this point in the conversation that Jordyn made the theory-practice connection underlying this theme: "...something I never had really thought of but the six dimensions of language arts...it's not just reading and writing but we always have different options..." Jordyn's "aha" moment hearkened back to her philosophy glog from the previous year as she connected theoretical understandings with her observations of the literacy opportunities they were trying to create.

Reading Mentors conveyed similar understandings as illustrated by the following 2013 survey response:

Let's Read! has reinforced the idea that there isn't just one way to go about teaching literacy - there are so many inventive and ingenious activities and ways to practice and enforce good literature.

Reading Mentors elaborated on this goal of creating diverse activities, not necessarily recognizing the tension the leaders felt to also "show" learning in a more concrete way for the parents. One way to address this sense of accountability raised by Reading Mentors involved sending a letter or email home each week to highlight the various literacy learning experiences that occurred during programming. They felt this would also help them to revisit learning opportunities as they continued to build their own repertoire of strategies and activities for future teaching/learning contexts.

\section{Capitalizing on Strengths}

As the program leaders sought to create diverse activities, they began to see the ways in which they might capitalize on children's strengths, the next key theme. Funds of knowledge, a term coined by González, Moll and Amanti (2005), rang true as teacher candidates talked both about the strengths they individually brought to the development of this initiative but also a recognition of working to build the strengths of the children, such as being able to offer differentiation through access to multiple Reading Mentors. Speaking about connecting with all the children, Kendra shared, "...you see that everyone has their strengths and weaknesses...." Similarly, one of the Reading Mentors shared, "I have learned what it takes to look after a child, and that all of them have their own personalities and strengths" (Survey Response, 2013). For Jordyn, observing how a child took on newfound leadership and engagement through an instructional recipe, reinforced to her how "...we need to capitalize on those strengths." She was recognizing the ways in which "students always bring knowledge to the classroom" (Literacy Philosophy Assignment).

Another example that stood out for the Program Leaders was the use of a signin board to scaffold the children's printing of their names as they arrived at each session. Jordyn observed how “...understanding what the letters look like by drawing a line down in the alphabet is just another way they can actually show you they know..." (Figure 1). Though perhaps a seemingly insignificant aspect of the overall program, this initial moment of signing-in reflected the careful thought of scaffolding and supporting literacy learning from the time the children walked through the door. It also demonstrated the ways in which Program Leaders took students' eyes' into account (Smith, 2002). Jordyn added that her "own experiences as a learner could 


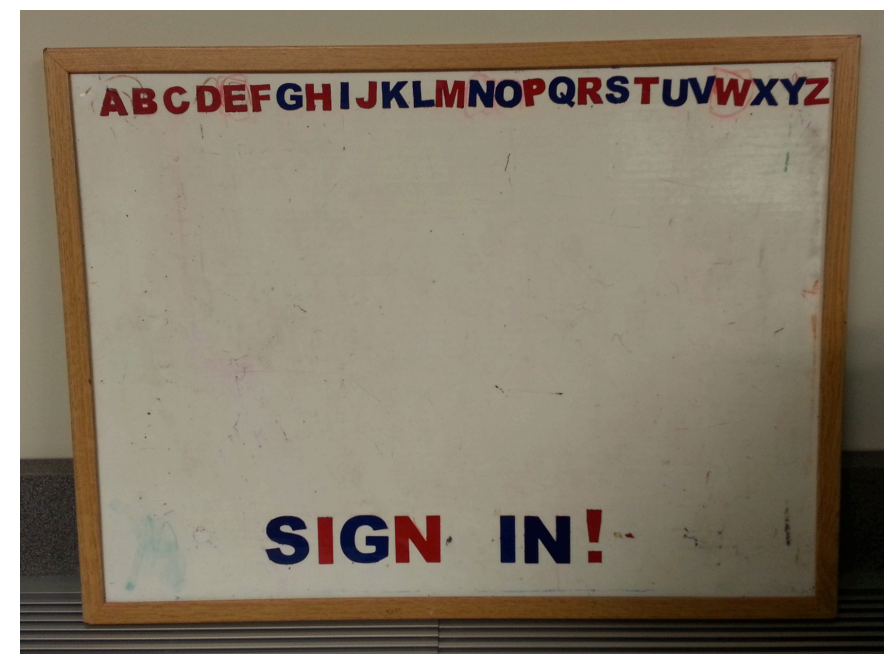

Figure 1. Sign-in Board

At the same time, a limitation raised by the Reading Mentors was that of limited time to get to know the children to differentiate and meet their individual strengths. Due to the nature of their roles and contact with parents, Program Leaders were better able to get to know individual learners, but the Reading Mentors sometimes felt a disconnect between their desire to adapt and personalize the learning experience for the child and the reality of their limited contact. One Reading Mentor explained, "I would say the only limitation I have faced is getting all that I can from my buddy because if they don't know or remember you, it's hard to get them to try and open up" (Survey Response, 2013). This tension, however, also challenged Reading Mentors to consider strategies they had learned about in class in order to try and build this connection.

Importantly, while the teacher candidates did not use the term "funds of knowledge", they recognized the various resources children brought to the learning situation. At the same time, a worry arose about how to value different funds within a classroom of learners. Jordyn shared,

I kind of worry [about] being able to teach a full classroom of kids without extra help...we see everyone's at a different level and everyone's thinking in a different way...that's why this program is so awesome because we always have a volunteer for each kid... and I'm just kind of like, 'am I going to be able to do this?...'

Pondering the tension of how to build on each child's strengths within a classroom, Kendra wondered, "...the silver lining... is that we do have to kind of overcome the fact that it's not just one grade of kids...there's a three-year gap." Further recognizing the diverse ages and abilities across learning contexts, Melanie added,

Every year was different... we had such a huge range of abilities in the group as well but that's something that you see everywhere right; you see that in every community, you see that wherever you are. 
Recalling course discussions about Cambourne's (1988) conditions for learning, the condition of engagement fits these reflections as teacher candidates consider the ways in which a task feels "doable" to the learners. Teacher candidates were beginning to recognize the strengths of the individual learners they were working with in the community, but it felt daunting to consider how they might do this as teachers within a classroom space. At the same time, these experiences added layers of new understandings about the ways in which engagement is central to the process of teaching and learning (Bainbridge \& Heydon, 2013). In fact, all of the themes noted so far were part of a layering process as teacher candidates worked to foster engagement through "communicating and modeling relevant reasons for becoming readers and writers" (Bainbridge \& Heydon, 2013, p. 36). As one of the Reading Mentors shared,

It allows them to find their own creative ways of how they can learn and still have fun. All of the activities could also be applied to real life events that students would need to understand. (Survey Response, 2013)

Taking up Cambourne's call for engagement, both the Program Leaders and Reading Mentors sought to create literacy learning opportunities that allowed learners to see themselves as potential "doers" of tasks that would further the purposes of their lives and from which they could engage without fear with trusted educators (the social nature of learning being evident here).

\section{Freedom in Planning/Freedom from Assessment}

The next theme focuses on freedom in planning and from assessment. While teacher candidates had opportunities to work on planning-related assignments in their coursework, they found planning for Let's Read! offered "more opportunity to work with kids, more opportunity to plan lessons..." (Kendra).

Invited by previous Program Leaders to begin planning in the summer, new Program Leaders spoke of greater opportunity to reflect and reconsider their planning ideas while taking courses in the Fall. Jordyn explained,

...but it was good because then we had our classes in the fall...talking to Kendra, talking to Melanie... [then] in my class [thinking], 'oooo, that's not going to work'... you know or I can make it better this way...

As Melanie reinforced, "encounter[ing] relevant class content and/or strategies" led to the revision of activities for greater literacy engagement.

Interestingly, an important distinction was raised between planning on practicum and planning for Let's Read! This distinction revolved around not having the same sense of choice in planning when on practicum. Kendra explained,

... it was nice to be able to have all that time to plan and to have our own choice in planning too.... when you go to placement...you're still kind of limited to, 'so I need you to teach math and I need you to teach 3D shapes'... it was nice being able to have it open.

Program Leaders appeared to feel greater freedom as emerging professionals when planning the community literacy sessions, a freedom that contributed to greater decision-making. 
Directly connected with the idea of freedom in planning was a consideration of freedom in relation to assessment, both in terms of coursework and practicum. Below, I share a snippet of our conversation as Melanie reflected further on limitations felt during practicum:

Melanie: ... especially if you have an AT with a different teaching style.... and might say, 'well, no you can't do that' or 'that wouldn't work'...you have more of the freedom to be [the teacher you want to be]...

Tara-Lynn: "I hear the idea that maybe there's no one assessing you..."

Jordyn: "That's good! (laughs)

Tara-Lynn: "...it's yourselves. You get to come up with the ideas, you get to try it out, you get to see if it works, you get to rethink it."

Melanie: "The fact that it's completely student-run is a huge aspect.

The return to the idea of a "student-run" initiative is key here as the teacher candidates sought to create a space where they could essentially "try out" or "become" the teachers they wanted to be.

Discussing the difference between the lesson plans they created in their coursework [not Language Arts specifically] and those for Let's Read!, Jordyn went on to explain:

I don't want this to come off in a negative way but I feel like if I'm planning a lesson for an Education class, I plan it differently than if I were to plan it knowing I'm going to implement it in the end...spend more time, more care thinking about, 'oh will this actually work, will what I want to come across actually come across', I mean I work hard in everything I do but in a different way....

Kendra supported this idea, adding:

As much as the lesson plans we do for class we can totally use in the future...this is an immediate reaction to what you have planned...you get that immediate feedback and response from the group of the children...it's more encouraging and [more meaningful] planning.

Program Leaders spoke to a strong sense of being able to build on beliefs and practices developed in their coursework but without the requirement of being assessed. Discussing the role of practice teaching in gaining professional knowledge, Pearce and Pollack (2012) posited that Matthew, the umemployed certified teacher in their study, "had more control and autonomy over his volunteer work" (p. 242). It may be that the Program Leaders similarly felt a greater sense of control and autonomy in their decision-making.

The tension that arises then is one of authentic purposes for assessment vs. "being assessed". How do we create opportunities for authentic, collaborative planning when teacher candidate's learning attempts are tied into receiving grades? Returning to Cambourne's conditions, it is the condition of response that echoes as I reflect on what these teacher candidates are saying. Despite efforts to provide rich, useful and timely feedback as instructors, this feedback differs from the kind of collaborative interchange for feedback that they valued within this community-based program. As such, those in the leadership role created a collaborative space for 
feedback that offered them "that extra set of eyes looking at something you wouldn't think of..." (Jordyn). This is not to say that they do not value the feedback we provide as instructors, but that it differs in terms of intent and perhaps goals, when it comes from a trusted peer/future colleague and is not tied in with assessment.

\section{Feedback from the Community}

In addition to the collaborative feedback they received from one another, Program Leaders also spoke of the feedback received from the community. Kendra reflected, "... [the parents] all just had good things to say about the program...it's nice to get the feedback that the program is doing well and helping build the community..." Jordyn also recalled a parent who after each session would say, "Oh, that's so awesome! You girls are doing such a good job!" The idea that teacher candidates created and led the program was central to the success they felt and the response they offered: “....we would tell them that it's entirely student run and they would be like, 'No, really?'...It's just nice to hear that what you're working so hard on is actually making a difference..." (Jordyn).

Reading Mentors expressed a similar valuing of the feedback received from the parents and children. One Reading Mentor spoke to how "the children always have smiles on their faces and talk about their experiences with their parents as they leave" (Survey Response, 2013). Another Reading Mentor highlighted the need to make these connections to the community in the first place:

This is a very rewarding initiative. It not only gives the preservice teachers a chance to expand on their skills but it also connects the University with the community. Students greatly benefit from this opportunity. (Survey Response, 2013)

Fitting of the program's initial goals, Melanie explained,

This was key to the development of the structure of the program, partly due to the geographic location of the university; we wanted a space that would bring us into the community, rather than force participants to come to us.

Teacher candidates also viewed this goal as a benefit to themselves. This initiative was "a way to be a part of the community and to get the opportunity to work with students outside their classroom" (Survey Response, 2013). This desire to connect with the community was also evidenced in the creative ways in which the Program Leaders aimed to spread the word about this community literacy initiative. Ideas included: handing out fridge magnets at the Santa Claus Parade, participating in local events, use of social media, etc. "But... at the end of the day, it's still word of mouth," acknowledged the Student Initiatives Coordinator, speaking to the ways in which the personal connections that the teacher candidates formed with children and parents led them to return and bring others with them. For the Program Leaders, community connections also helped to overcome initial limitations surrounding funding and resources. Time spent working with the children, along with feedback from the community, led them to persist in their goals.

Cambourne's (1988) condition of response is once again echoed here as teacher candidates not only receive feedback but also return feedback to parents by sharing/celebrating learning moments. In doing so, they are also recognizing parents as models and supporters of their children's literacy growth, a topic we first discuss in 
relation to the concept of emergent literacy. It is perhaps also why Program Leaders felt the need to share print literacy materials with parents to show the learning taking place. As they think of ways to communicate with parents, such as the newsletter suggested by Reading Mentors, Program Leaders are expanding what it means to include parents as partners.

\section{Becoming Literacy Leaders}

The underlying journey for the Program Leaders is that of becoming literacy leaders, both in the community with parents and children, and with their peers. In their leadership roles, they demonstrated an ongoing passion for teaching literacy and language arts, a passion I suspect will continue into their future teaching positions. Their peers recognized this throughout the surveys as they spoke repeatedly to the "interesting," "creative," and "varied," activities, as well as the overall organization of the program. Several Reading Mentors also shared how they looked to the ideas and opportunities created by those in leadership roles. One Reading Mentor explained: "I really enjoyed seeing and using the various activities put together each week for the young readers - they will be excellent sources for when I myself am a teacher" (Survey Response, 2013). Recipe Days, such as Making Flubber (Figure 2), were noted by Reading Mentors for their interactive nature and application to real life events (e.g. reading and writing recipes). Understandings of whole-part-whole instruction (Purcell-Gates \& Waterman, 2000) were also evident as Program Leaders drew upon children's literature to create opportunities for "learning with, through, and about whole texts" (Iannacci, 2013, p. 65), such as Seven Blind Mice (Figure 3), which provides an example of a shared, interactive read-aloud. Follow-up activities then focused on the parts of language (e.g. Popcorn Story Words, Figure 4), as well as opportunities to apply understandings through writing and art.

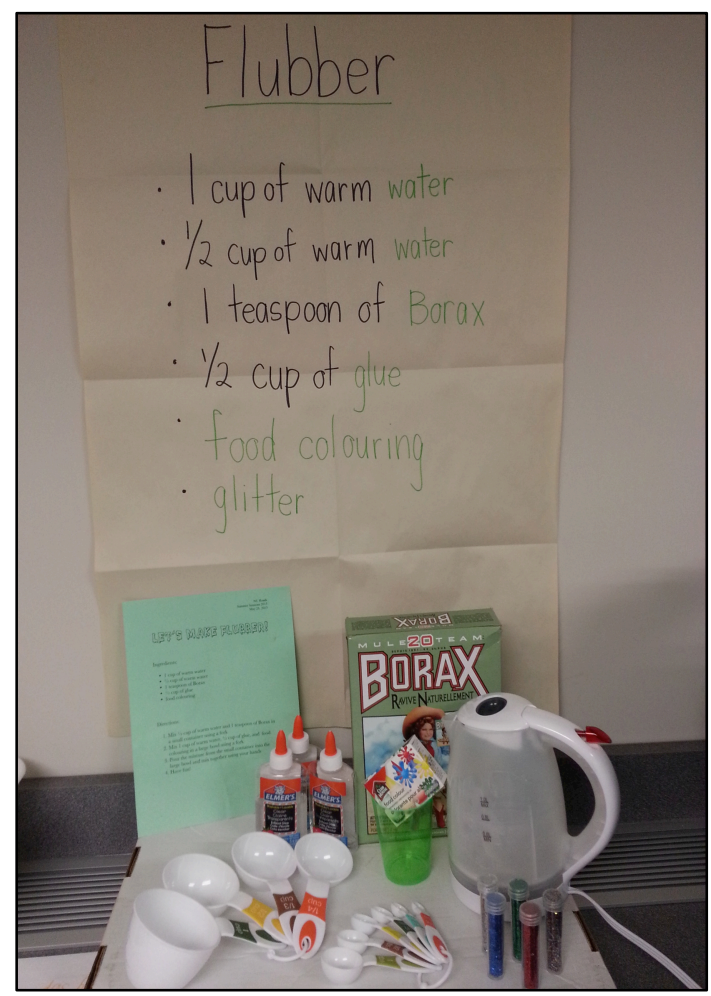

Figure 2. Instructional Recipes, such as Making Flubber 


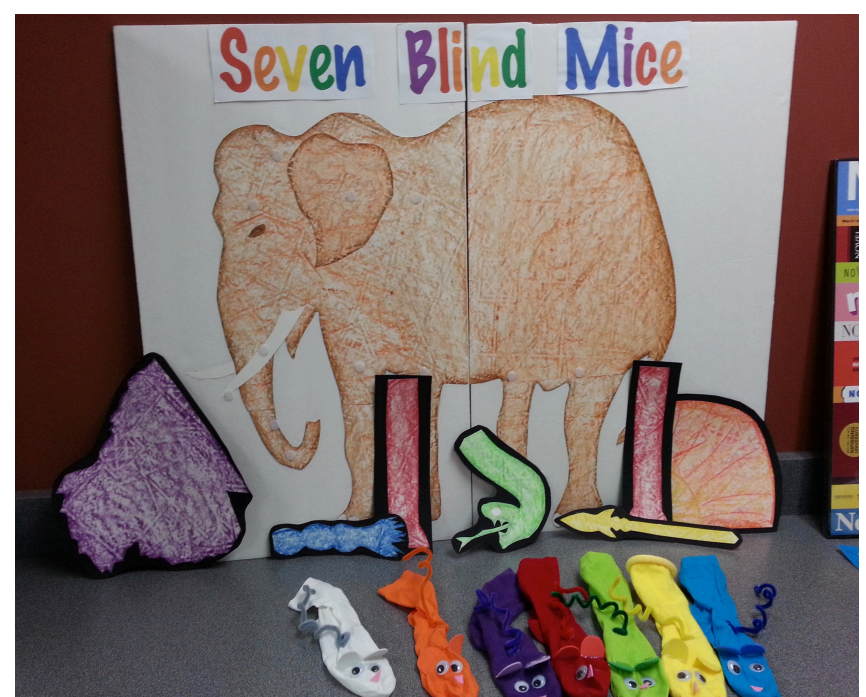

Figure 3. Interactive Reading of Seven Blind Mice by Ed Young

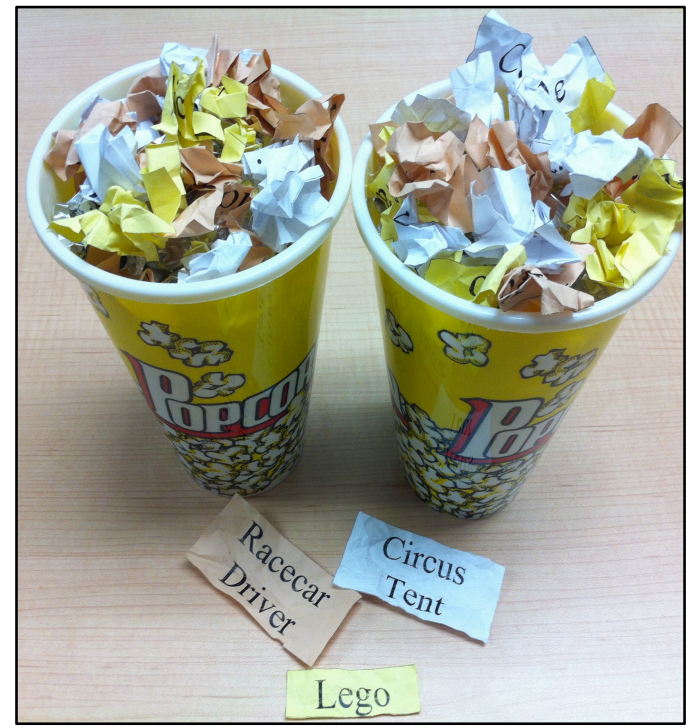

Figure 4. Popcorn Story Words

Recognizing both the leadership and mentorship potential of the teacher candidates involved, the university's Student Initiatives Coordinator, an early supporter of the program (both administratively and financially), observed:

...I just thought this is a program that we can harness...for the ideas and the excitement, the enthusiasm, the way they engage other students. They created a new dynamic experience and...I saw what their potential was as they stepped up to the leadership role, which is very rare I think...

For the Student Initiatives Coordinator, the student-led aspect of the program represented a unique strength. It is also what contributed to the embedded sense of mentorship within the program, another influence in becoming literacy leaders to which I will turn next. 


\section{Expanding Upon Mentorship Roles}

Rowley (1999) identified six qualities of good mentors: committed, accepting, skilled, effective communicators, models of ongoing learning, and conveyers of hope and optimism. While all of Rowley's (1999) qualities were recognized by the Program Leaders, two stood out as central. First, communication was identified for its impact on the success of the program. Mira explained, "Communication is key in the program, as there is a bit of a ladder-effect when it comes to mentoring. We need to communicate clearly with the [reading] mentors, so that they can communicate well with the child." Despite this ladder-effect, Jordyn viewed the need for communication as occurring across all the mentoring relationships and, noted the importance of listening to one another, sharing ideas, and effective interpersonal skills.

Second, being a role model was central to the way in which the Program Leaders viewed both themselves and the multiple mentorship relationships within the program. Jo explained, "we must be role models for volunteers and participants taking part...it not only demonstrates the professionalism...but the attitudes we instill about learning and reading". At the same time, Program Leaders recognized the importance of ongoing learning and development across mentorship relationships (Hibbert, 2006; Rowley, 1999). Jordyn emphasized, "we all learn from each other, whether we are in the position of the mentor or the mentee." Similarly, Kendra added, "I enjoy the reciprocal expectations for both mentors and mentees... Shows that it is not an authoritative relationship we are trying to engage in, but a supportive, collaborative one."

Figure 5 depicts the mentorship relationships spoken of by the Program Leaders. Reminiscent of the gradual release of responsibility learned about in their coursework, these relationships reflect a similar movement from greater to lesser degrees of mentorship support. This embedded structure was crucial to the both maintaining the program's growth, and the evolving nature of the Program Leader role. Table 1 shares examples of the tasks identified as part of these roles.

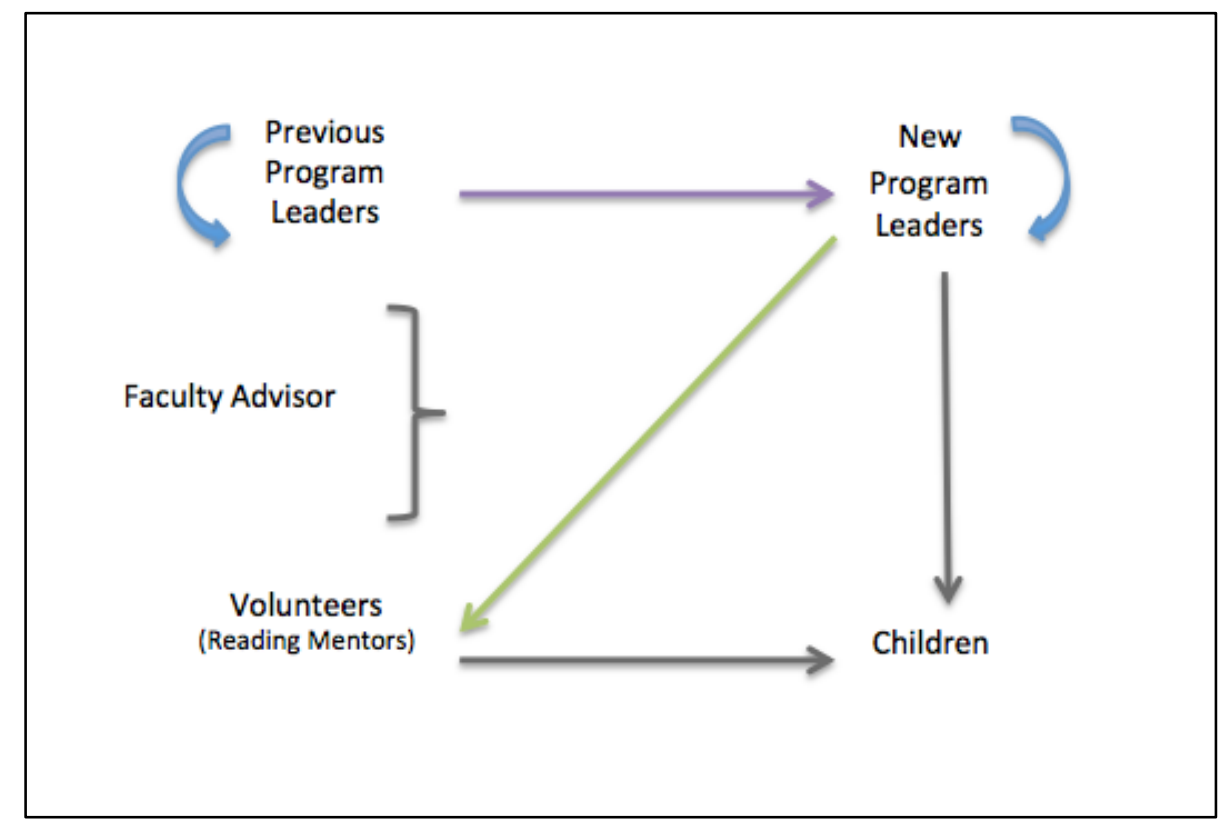

Figure 5. Mentorship Relationships 
Table 1

Mentoring Tasks and Opportunities

\begin{tabular}{|c|c|}
\hline Mentoring Relationship & Mentoring Tasks \& Opportunities \\
\hline $\begin{array}{l}\text { Previous Program Leaders } \\
\text { to New Program Leaders } \\
\text { (purple arrow) }\end{array}$ & $\begin{array}{l}\text { - creating/revising a Leader Handbook } \\
\text { - administrative duties } \\
\text { - introductions to key players around the university and } \\
\text { community } \\
\text { - modeling sessions } \\
\text { - responding to questions }\end{array}$ \\
\hline $\begin{array}{l}\text { Between Co-Leaders } \\
\text { (blue arrows) }\end{array}$ & $\begin{array}{l}\text { - collaborative planning, } \\
\text { - learning from one anther (playing off one another's } \\
\text { strengths) } \\
\text { - gaining trust } \\
\text { - building communication skills } \\
\text { - becoming a team as opposed to simply being co- } \\
\text { workers }\end{array}$ \\
\hline $\begin{array}{l}\text { New Program Leaders to } \\
\text { Reading Mentors (green } \\
\text { arrow) }\end{array}$ & $\begin{array}{l}\text { - model activities prior to the beginning of sessions } \\
\text { - lead whole group introduction related to themed } \\
\text { session, they then } \\
\text { - following whole group introduction, hand over } \\
\text { responsibility to the Reading Mentors to work the } \\
\text { children } \\
\text { - hold information sessions to recruit mentors, as well } \\
\text { as appreciation days for those who volunteer }\end{array}$ \\
\hline $\begin{array}{l}\text { Program Leaders/Reading } \\
\text { Mentors to Children (grey } \\
\text { arrows) }\end{array}$ & $\begin{array}{l}\text { - mentoring one-on-one to children during literacy- } \\
\text { related activities } \\
\text { - displaying positive reading attitudes (a foundational } \\
\text { purpose of the program) } \\
\text { - building rapport/trust with children } \\
\text { - assessing children's strengths and needs to benefit the } \\
\text { learning experience taking place }\end{array}$ \\
\hline
\end{tabular}

Building on this mentor-mentee duality within the program are the ways in which teacher education programs can support the mentorship opportunities taking place. Returning to Rowley's (1999) qualities of good mentors, two different qualities stood out as key to the Faculty Advisor role. The first, committed, recognized the ways in which mentors demonstrate a valuing of mentorship as "part of the process of making a difference in the lives of teachers and students" (Hibbert, 2006, n.p.). A second quality emphasized by Program Leaders was that of being skilled, in particular, providing instructional strategies and support (Hibbert, 2006; Rowley, 1999). Perhaps not surprising, Program Leaders were looking for an advisor that shared a similar passion for the program, and importantly, resources! It was exactly these kinds of mentoring supports that were spoken of by the Student Initiatives Coordinator when envisioning new directions of support for the program: 
I think it needs a better connection to the Faculty of Education in a more formal way...to give more guidance to it. Because I don't go into programming so I rely on the students to consult and ensure the program's credible.

Program Leaders viewed the Faculty Advisor as fitting of this goal, which led to my invitation to take on this role. Important to note, the Faculty Advisor serves a guiding mentorship role in order that the pattern of leadership established at the program's onset be continued.

\section{Looking Ahead}

This project has provided a rich opportunity to learn more about Let's Read!, a teacher-initiated community-based initiative. In doing so, it also raises questions for ongoing reflection and conversation, such as:

- How can we continue to support programs initiated by teacher candidates, such as the one shared in this paper? Implications for the university and community at large?

- In what ways can we incorporate a greater sense of freedom in planning and from assessment in our teacher candidate's teaching attempts?

- What other volunteer opportunities contribute to teacher candidates' understandings of teaching literacy and language arts?

From both an advisory and research-related perspective, a more personally driven question is that of how I continue to support, reflect and problem-solve alongside teacher candidates without influencing the student-led aspect of the program that is viewed as central by participants?

In conclusion, I return to the tensions mentioned as the Program Leaders shared their experiences. While at times seen as roadblocks, these tensions were a key part of their journey to becoming literacy leaders. Speaking to the tensions faced by new teachers as they enter the profession, Turner, Applegate and Applegate (2011) offer five suggestions to encourage new teachers to take on the role of literacy leader. These suggestions highlight the importance of vision, creative instruction, parent partnerships, purposeful assessment, and lifelong reading. As demonstrated in this article, teacher candidates involved with Let's Read! fit many of these suggestions, in particular the goal of modeling lifelong reading, and designing creative programming that works for the children enrolled. Throughout, it is evident these teacher candidates are refining their vision as they build upon course-related understandings within this community-based initiative. They are indeed involved in the learning process spoken of earlier by Bainbridge and Heydon (2013) as they make critical, reflective decisions in response to challenges and demands. My hope is that these teacher candidates continue to see possibilities within tensions, continually assuming a literacy leader role for their students, school and community.

\section{References}

Assaf, L. C., \& Lopez, M. (2012). Reading rocks: Creating a space for preservice teachers to become responsive teachers. Journal of Early Childhood Teacher Education, 33(4), 365-381. 
Bainbridge, J., \& Heydon, R. (2013). Constructing meaning: Balancing elementary language arts. $\left(5^{\text {th }}\right.$. Ed.). Toronto, ON: Nelson Education.

Baker, P. H., \& Murray, M. M. (2011). Building community partnerships: Learning to serve while learning to teach. School Community Journal, 21(1), 113-127.

Cambourne, B. (1988). The whole story: Natural learning and the acquisition of literacy in the classroom. Newtown, Australia: Primary English Teachers Association.

Chicola, N. A., \& Ceprano, M. (2009). Preservice Teachers Collaborating with Families to Foster Global Literacy Connections. International Journal Of Learning, 16(8), 221-233.

Clift, R., \& Brady, P. (2005). Research on methods courses and field experiences. In M. Cochran-Smith \& K. Zeichner (Eds.), Studying teacher education: The report of the AERA panel on research and teacher education (pp. 309-424). Mahwah, NJ: Lawrence Erlbaum Associates.

Dyson, A. H. \& Genishi, C. (2005). On the case: Approaches to language and literacy research. New York, NY: Teachers College Press.

Garner, G., \& Rosaen, C. (2009). Strengthening partnerships and boosting conceptual connections in preservice field experience. Teaching Education, 20(4), 329342.

González, N., Moll, L., \& Amanti, C. (2005). Funds of knowledge: Theorizing practices in households, communities, and classrooms. Mahwah, NJ: Lawrence Erlbaum.

Grossman, P., Valencia, S., Evans, K., Thompson, C., Martin, S., \& Place, N. (2000). Transitions into teaching: Learning to teach writing in teacher education and beyond. Journal of Literacy Research, 32, 631-662.

Hibbert, K. (2006). Building a culture that supports mentoring in schools: Tips and ideas for teachers and administrators. Continuing Teacher Education, UWO.

Iannacci, L. (2013). Enriched instructor's manual to accompany Constructing Meaning: Teaching the Language Arts K-8 (5th Ed.). Toronto, ON: Nelson Education.

Iannacci, L., \& Graham, B. (2010). Mind the gap: Destabilizing dominant discourses and beliefs about learning disabilities in a Bachelor of Education program. The Alberta Journal of Educational Research, 56(3), 27-290)

Kosnik, C., \& Beck, C. (2008). We Taught Them about Literacy but What Did They Learn? The impact of a preservice teacher education program on the practices of beginning teachers. Studying Teacher Education: Journal Of Self-Study Of Teacher Education Practices, 4(2), 115-128.

Purcell-Gates, V. (1996). Stories, coupons and the TV Guide: Relationships between home literacy experiences and emergent literacy knowledge. Reading Research Quarterly, 31, 406-428.

Purcell-Gates, V. (2008). Authentic literacy instruction K-3: A handbook for teachers. Available at http://cpls.educ.ubc.ca/content/research.html

Purcell-Gates, V., \& Waterman, R. A. (2000). Now we read, we see, we speak. New York, NY: Routledge.

Richards, J. C. (2007). A community of practice summer literacy camp: One way to connect preservice teachers, graduate education majors, and elementary children. Journal of Reading Education, 32(2), 40-43.

Richards, J. C. (2006). Preservice teachers' professional development in a community of practice summer literacy camp for children at-risk: A sociocultural perspective. The Qualitative Report, 11(4), 771-794. 
Roessingh, H. (2012). Service learning and student engagement: A dual language book project. Canadian Journal of Education, 35(4), 284-307.

Rowley, J.B. (1999). The good mentor. Educational Leadership, 56(8), $20-22$.

Pearce, J., \& Pollock, K. (2012). Informal learning and volunteering: The case of an unemployed certified teacher in Ontario. LEARNing Landscapes, 5(2), 237250.

Smith, P. M. (2008). Learning how to teach: A supported literacy coaching program for pre-service teachers. International Journal of Learning, 15(6), 271-280.

Smith, P. (2002). A reflection on reflection. Primary Voices K-6, 10(4), 31-34.

Taylor, D. (1983). Family literacy: Young children learning to read and write. Exeter, New Hampshire: Heinemann Educational Books.

Thomas, G. (2011). How to do your case study: A guide for students \& researchers. Thousand Oaks: CA

Turner, J. D., Applegate, A. J., \& Applegate, M. D. (2011). New teachers as literacy leaders. The Reading Teacher, 64(7), 550-552.

Vygotsky, L. (1978). Mind in society: The development of higher psychological processes. (M. Cole, V. John-Steiner, S. Scribner, \& E. Souberman, Eds.). Cambridge, MA: Harvard University Press.

Wasserman, K. B. (2009). The role of service-learning in transforming teacher candidates' teaching of reading. Teaching and Teacher Education, 25(8), 1043-1050.

Author Biography

Tara-Lynn Scheffel is an Associate Professor in the Schulich School of Education, Nipissing University, Ontario, Canada. Research interests include literacy engagement, teacher education and the sharing of practitioner stories. 